\title{
A CASE OF PRIMARY OVARIAN LOW-GRADE ENDOMETRIAL STROMAL SARCOMA
}

\author{
Woo Hee Yi, MD¹, Kyu Sik Shin, MD¹, Goo Hwa Je, MD¹, Hwa Sun Lee, MD², Kyung Don Baik, MD \\ Departments of ${ }^{1}$ Obstetrics and Gynecology, ${ }^{2}$ Pathology, Busan St. Mary's Medical Center, Busan, Korea
}

Endometrial stromal sarcoma (ESS) is a relatively rare form of uterine sarcoma. ESS of the myometrium compose just $0.2 \%$ of uterine malignant tumors. Low-grade ESS has extended beyond the uterus in $40 \%$ of cases at the time of diagnosis. ESS of ovary is very rare. Most of ovarian ESS is concomitant with endometriosis or same tumor in uterus. We have experienced a primary ovarian low-grade ESS, and that sarcoma is localized in ovary. So, we report this case with review of literature.

Keywords: Sarcoma, endometrial stromal, low grade; Ovarian neoplasms

자궁외에서 일차적으로 발생하는 자궁내막기질육종은 매우 희귀하 다[1].

자궁내막기질육종(endometrial stromal sarcoma, ESS)은 자궁육종의 비교적 드문 형태로서 자궁육종의 $7 \%-15 \%$ 를, 모든 자궁 악성 종양의 $0.2 \%$ 를 차지하고 있으며[2], 대부분 자궁근층으로 침윤하거나 자궁내 막강내로 돌출하는 자궁내 종괴를 형성하지만, 간혹 자궁내 종양이 없 이 난소, 난관, 광인대, 자궁근처, 장간막, 후복막강, 골반강, 복강과 S상 결장, 횡행결장 등 대장의 고유근층과 장막에 원발성 종괴를 형성하기 도 한다[3-5].

저자들은 49세의 기혼 여성이 내원 당일 아침부터 시작된 복통으로 인해 촬영한 computed tomography (CT)상 골반내 고형성 난소종괴 또는 비정형적인 자궁근종이 의심되어 시험적 개복술을 시행하였고, 조직검사 결과 난소에서 일차적으로 발생한 저등급 자궁내막기질육종 (low-grade ESS)로 진단된 아주 드문 1예를 경험하였기에 문헌고찰과 함께 보고하는 바이다.

\section{증 례}

환 자: 배 O O, 49세, 기혼

주 소: 내원 당일 아침부터 시작된 복통

산과력: 2-0-0-2, 2회의 제왕절개분만이 있었다.

월경력: 14 세에 초경이 있었고, 주기는 불규칙적이고, 기간은 7일 정 도이며, 월경량은 소량이었으며, 월경통은 없었다.

과거력: 2회의 제왕절개술 및 충수돌기절제술을 시행받았다.

가족력: 특이사항은 없었다.

현병력: 환자는 2011년 1월 내원 당일 아침부터 발생한 복통으로 한
의원, 개인내과의원 및 본원외과를 방문하여 CT를 시행하였다. CT상 골반내 $11.6 \times 9.2 \mathrm{~cm}$ 크기의 고형성 난소종괴 또는 비정형적인 자궁근 종이 의심되는 종괴가 관찰되어 본원 산부인과로 의뢰되었다. 본원에 서 시행한 경질초음파 소견상 골반내에 기시부가 불분명한 종괴가 확 인되어 외래를 통해 입원하였다.

이학적검사 소견: 내원 당시 환자의 의식상태는 명료하였고, 신장은 $162 \mathrm{~cm}$, 체중 $59.5 \mathrm{~kg}$, 혈압은 100/60 mm Hg, 맥박수는 66회/분, 호 흡수는 20 회/분, 체온은 $36.4^{\circ} \mathrm{C}$ 였고, 영양상태는 양호하였으나 심한 복통을 호소하였다. 복부검사상 하복부에 수술반흔이 있었고 하복부의 종물이 만져졌다. 장음은 정상이었다. 내진 소견상 기시부가 불분명한 종괴가 치골결합 상부에서 촉지되었고, 촉진 시 압통과 반발통이 동반 되었다.

검사실검사 소견: 말초혈액검사에서 백혈구 $9,560 / \mathrm{mm}^{3}$, 혈색소 12.7 $\mathrm{g} / \mathrm{dL}$, 혈소판 $248,000 / \mathrm{mm}^{3}$, C반응성 단백질 $10.47 \mathrm{mg} / \mathrm{L}$ 이었고, 소

Received: 2012.2.8. Revised: 2012.4.4. Accepted: 2012.4.4. Corresponding author: Kyung Don Baik, MD

Departments of Obstetrics and Gynecology, Busan St. Mary's Medical Center, 25-14 Yongho-ro, 232beon-gil, Nam-gu, Busan 608-838, Korea

Tel: +82-51-933-7227 Fax: +82-51-932-8600

E-mail: kdbaik@hanmail.net

This is an Open Access article distributed under the terms of the Creative Commons Attribution Non-Commercial License (http://creativecommons.org/licenses/ by-nc/3.0/) which permits unrestricted non-commercial use, distribution, and reproduction in any medium, provided the original work is properly cited.

Copyright @ 2012. Korean Society of Obstetrics and Gynecology 


\section{KOREAN JOURNAL OF OBSTETRICS \& GYNECOLOGY}

KJOG Vol. 55, No. 9, 2012
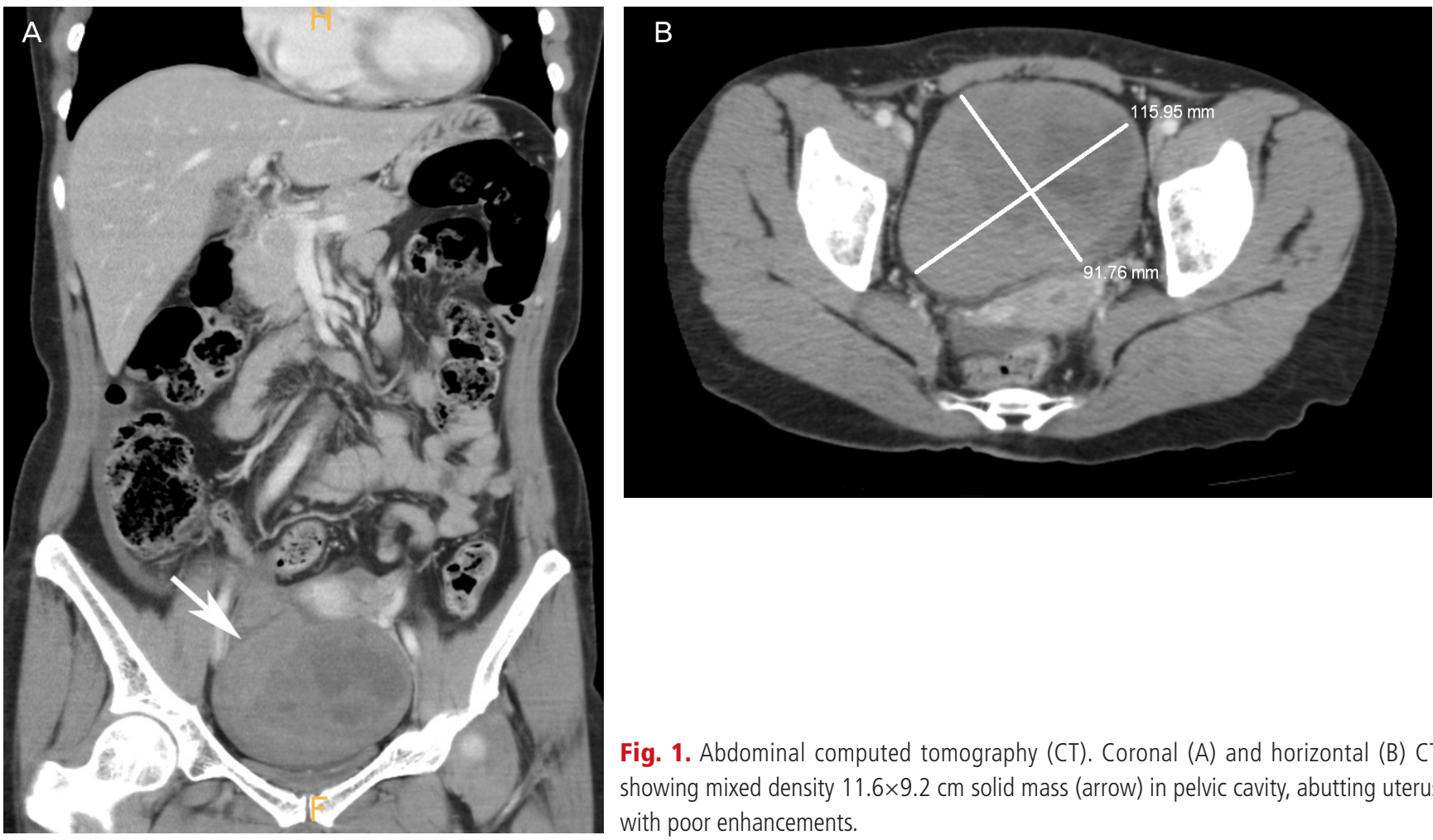

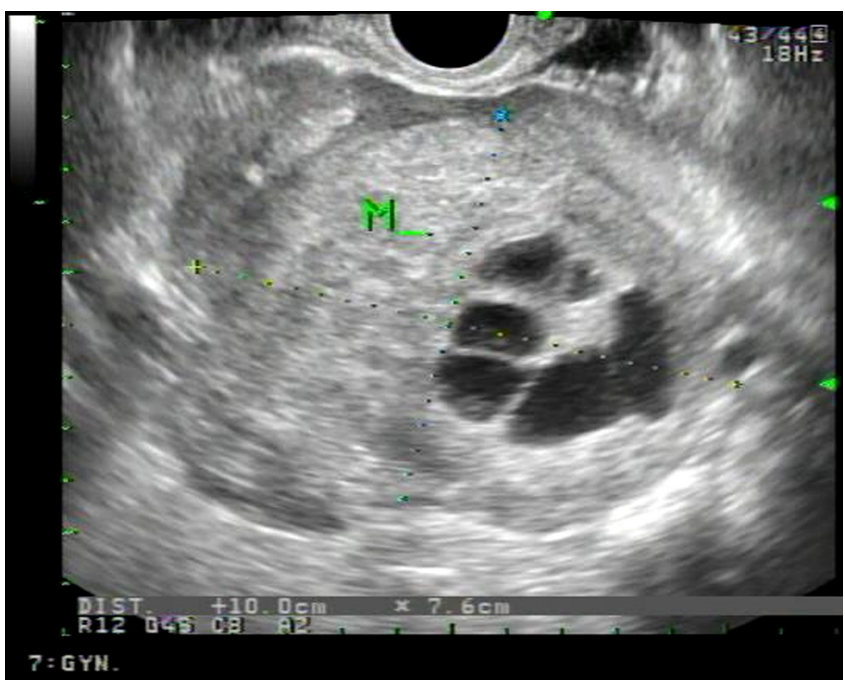

Fig. 2. Transvaginal ultrasonography shows mixed echogenic solid mass in pelvic cavity.

변검사에서 잠혈(-), 적혈구 <1/HPF, 백혈구 <1/HPF였다. 종양 표 지자검사에서 CA-125 $12.3 \mathrm{U} / \mathrm{mL}, \mathrm{CA} 19-93.92 \mathrm{U} / \mathrm{mL}, \mathrm{CA} 72-4$ $2.34 \mathrm{U} / \mathrm{mL}$, carcinoembryonic antigen $0.45 \mathrm{ng} / \mathrm{mL}, \alpha$-fetoprotein 3.3 $\mathrm{ng} / \mathrm{mL}, \beta$-human chorionic gonadotropin $1.1 \mathrm{IU} / \mathrm{L}$ 로서 정상범위였고, squamous cell carcinoma antigen은 $3.1 \mathrm{ng} / \mathrm{mL}$ 로서 정상 참고치보다 높은 소견을 보였다. 자궁경부 세포검사상 특이 소견을 보이지 않았다.
컴퓨터단층촬영검사 소견: 상복부 및 골반전산화촬영 결과 좌측 신장 에 작은 결석이 발견되었으며, 골반강내에 우측 난소고형종괴 또는 비 전형적인 자궁근종으로 의심되는 비균질적인 음영을 띠는 $11.6 \times 9.2$ $\mathrm{cm}$ 크기의 종괴가 관찰되었다. 골반내 림프절비대 소견은 관찰되지 않 았다. 우측 복강내 복수가 관찰되었다(Fig. 1).

초음파촬영 소견: 경질 초음파 소견상 골반내에 기시부가 불분명한 $11.0 \times 7.6 \mathrm{~cm}$ 크기의 종괴가 관찰되었다. 더글라스와에서 혈복강으로 의심되는 복수가 관찰되었다(Fig. 2).

수술소견: 2011년 1월 21일 전신마취하에 개복술을 시행하였다. 개복 시 하복부에 $11 \times 9 \times 7 \mathrm{~cm}$ 크기의 종괴가 관찰되었다. 이 종괴는 일부 파열된 상태로 $720^{\circ}$ 정도 시계방향으로 염전되어져 있었고 출혈경색 된 상태였다. 복강내에는 $500 \mathrm{~mL}$ 정도의 갈색의 복수가 차 있었고, 복 벽과 그물막 사이의 유착도 관찰되었다. 우측 난소종괴의 동결절편생 검상 자궁내막기질육종 소견보여 전자궁절제술 및 양측 자궁부속기절 제술과 함께 골반림프절절제술 및 부분대망절제술 및 유착제거술을 시 행하였다.

병리조직학적 소견: 1) 육안적 소견: 종괴의 크기는 $11 \times 9 \times 7 \mathrm{~cm}$ 이었 으며 적색에서 짙은 갈색을 띤 고형의 울혈된 양상이 관찰되었다. 종괴 는 파열된 상태였다.

2) 현미경적 소견: 자궁내막기질세포와 닮은 난원형의 종양 세포가 혈관 주변을 둘러싸듯 배열하고 있었다(Fig. 3). 종양세포들은 원형 및 난원형의 핵과 적은 양의 세포질을 가졌으며, 세포의 다형성은 보이지 않았고, 세포분열은 관찰되지 않았다(Fig. 4). 종괴의 염전 때문에 혈관 


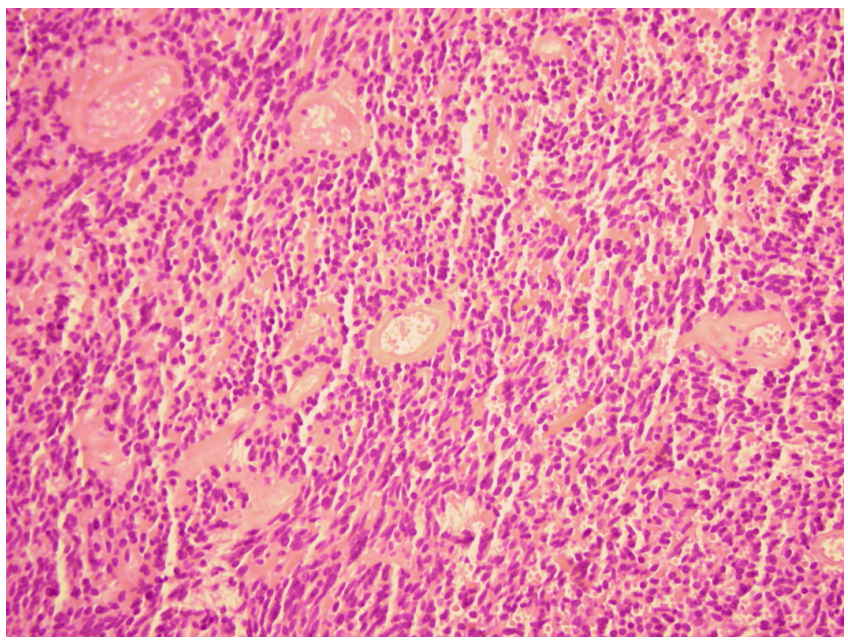

Fig. 3. Dense cellular neoplasm, composed of ovoid cells with interspersed small arterioles $(H \& E, \times 40)$.

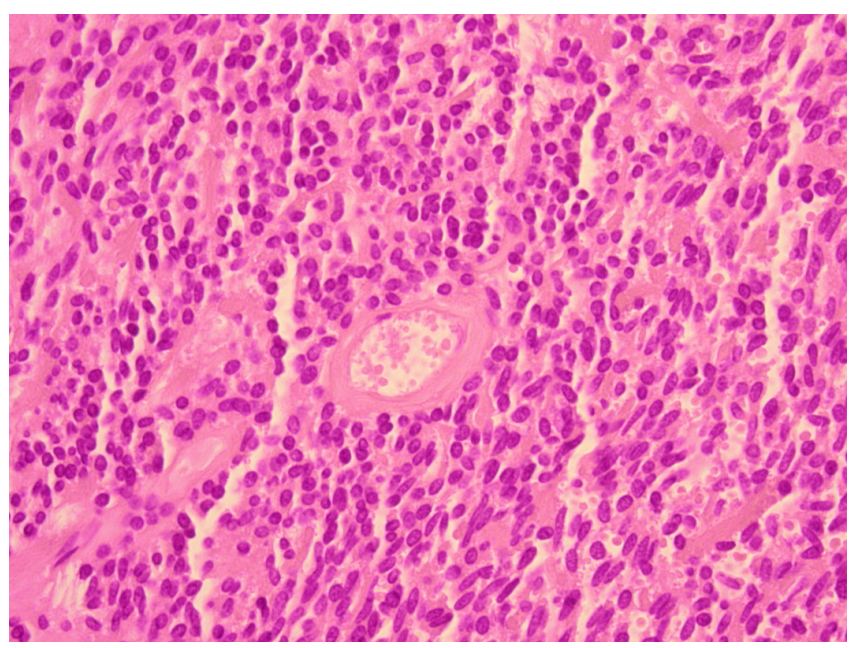

Fig. 4. The ovoid tumor cells are arranged concentrically around the spiral arterioles $(H \& E, \times 200)$.

은 다소 확장되어 있었고, 기질에 출혈이 관찰되었다(Fig. 5).

3) 면역조직화학염색 소견: 종양세포들은 vimentin 양성이었고, smooth muscle actin, desmin, leucocyte common antigen, estrogen receptor, progesteron receptor, cytokeratin에 음성이었다. 종괴 는 일부 파열된 상태로써 International Federation of Obstetrics and Gynecology stage에 따른 환자의 전체적 병기는 IC였다.

수술 후 경과: 수술 후 환자의 경과는 양호하였고, 특별한 합병증은 없었다. 수술 후 4개월 뒤인 2011년 5월에 시행한 positron emission tomography-computed tomography (PET-CT)상 재발이나 전이에 대 한 특이소견 없었으며, 이후 6개월 뒤인 2011년 11월에 다시 시행한 $\mathrm{PET}-\mathrm{CT}$ 상에도 역시 특이 소견 보이지 않아 외래를 통한 경과 관찰을 하고 있다.

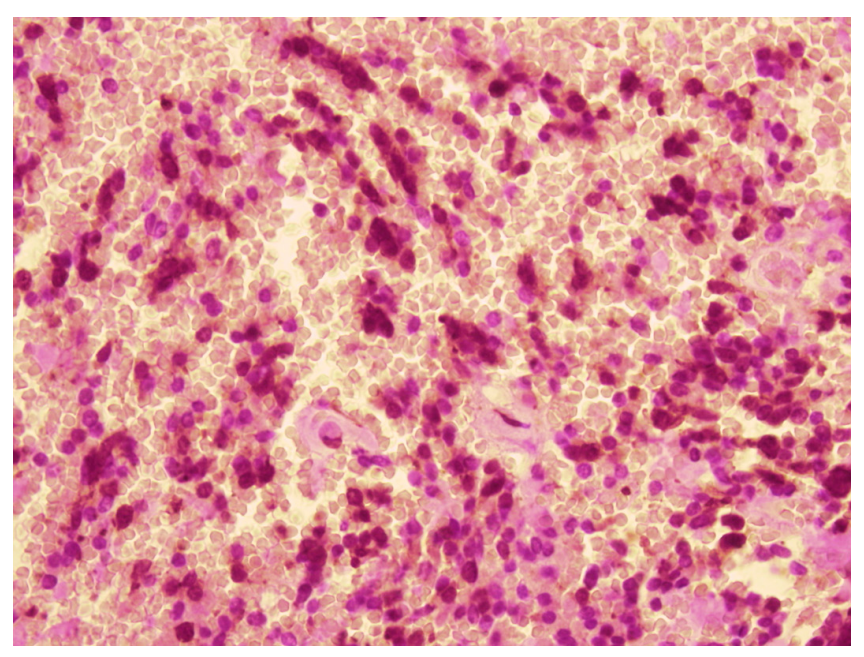

Fig. 5. Interstitial hemorrhage and congestion, due to torsion (H\&E, $\times 200$ ).

\section{고 찰}

자궁육종은 자궁의 중배엽 조직인 간엽 조직 또는 결체 조직에서 발 생하는 비교적 드문 악성 질환으로 자궁에서 발생하는 악성 종양의 $2 \%-6 \%$ 에 불과하며[2], 자궁외에서는 더 희귀하다[1].

자궁육종의 가장 흔한 세 가지 조직학적 변형은 자궁내막기질육종, 자궁평활근육종(leiomyosarcoma), 악성 혼합밀러씨종양(malignant mixed mullerian tumor)이다.

이 중 본 증례보고에서 다루고자 하는 자궁내막기질육종은 자궁육종 의 약 $10 \%$ 를 차지하고 있고, 세포분열중인 세포의 수에 따라, 저등급 ESS (low grade ESS)와 고등급 ESS (high grade ESS)로 구분된다[6]. $\mathrm{ESS}$ 의 약 2/3를 차지하고 있는 저등급 ESS는 현미경 $10 \mathrm{HPF}$ 당 핵분 열상이 10 개 미만의 침윤성 종양으로[6], 첫 치료 시작 후 평균 5년이 내 약 $1 / 2$ 에서 재발하지만[7], 비교적 예후가 좋고 재발 후에도 오랜 기간 생존하며 완치가 가능할 수 있다[8]. 고등급 ESS는 전체 ESS의 약 $1 / 3$ 을 차지하고 있고, $10 \mathrm{HPF}$ 당 핵분열상이 10 개 이상으로 자궁근 육층내로 더 심하게 침윤하며, 종종 전이가 있고, 5 년 무병생존율이 약 $25 \%$ 로 예후가 매우 나쁘다[6]. 전이는 정맥이나 임파선을 통해 광인대 와 자궁부속기, 주인대, 질, 방광 등에 있을 수 있으며, 원격전이는 간, 폐, 골격, 뇌 등에 가능하다.

자궁외에서 발생하는 ESS의 병인은 현재까지 확실하지 않지만 대 부분의 증례에서 자궁외에 존재하는 자궁내막조직이 종양의 근원 이 된다고 생각된다. 이 경우 내인성 또는 외인성 에스트로겐이 이들 조직의 악성 변형에 역할을 할 것으로 생각된다. 또한 난소중피세포 (ovarian surface mesothelium) 또는 체강하 간엽에서의 화생의 가능 성도 있다[1].

자궁내막기질육종은 45-50세의 폐경기 전후의 여성에게서 발생하 며, $1 / 3$ 은 폐경된 여성에게서 발생하고, 출산력, 동반된 질환, 이전의 골반내 방사선치료와의 연관성은 없다[7]. 
증상은 복부 및 골반 종괴가 촉지되거나, 하복부 동통, 또는 종양에 서의 출혈 등이 흔하다[1]. 그러나 질병 자체가 희귀하고 증상과 증후 가 특이한 것이 없으므로 수술 전 진단은 매우 힘들며, 대부분은 수술 후 병리검사 시행 후 확진하게 된다.

조직학적으로는 정상 증식기 내막의 선이나 간질에서 기원하는 세포 와 유사한 세포들의 침습적 증식으로 특징되는데, vimentin, 근육-선택 적 actin, 평활근 actin, 그리고 desmin에 대하여 면역학적 반응을 보인 다는 것이다[9]. 본 증례에서도 면역조직화학염색 소견에서 vimentin에 양성 소견을 보였다.

자궁내막기질육종의 치료는 외과적 수술, 호르몬요법, 항암화학요법, 방사선요법 등이 있다. 이 질환의 빈도 자체가 적기 때문에 체계적인 치료법이 정립되어 있지 않으나, 적절한 일차 치료로는 전자궁절제술 및 양측 자궁부속기절제술을 시행함과 동시에 육안적으로 보이는 모든 종양을 수술적 방법으로 제거하는 것이 권장된다[10,11]. 에스트로겐 이 종양성장을 촉진하는 것으로 알려져 있고, 종양이 자궁방결합조직, 광인대 및 자궁부속기를 통해 전파될 수 있기 때문에 자궁부속기는 반 드시 제거되어야 한다.

호르몬치료로는 megesterol acetate, medroxyprogesterone acetate 등 황체호르몬제제가 많이 사용된다. 주로 재발된 경우나 진행된 경 우에 사용되며, 많은 연구들에서 대부분의 저등급 ESS와 일부 고등급 ESS에서 progesterone 수용체가 존재함이 증명되었다[8]. Piver 등[8] 은 13 명의 환자 중 6 명에서 프로제스틴치료에 명백히 반응함을 지적 하였고, Baker 등[12]은 progesterone수용체 검사가 양성의 결과를 보 이면 progesterone치료가 타당하다고 하였다. 또한 폐전이가 있는 경 우 progesterone 치료가 전이 부위의 크기를 현저하게 감소시킨 예도 있었다[3].

화학요법의 효과는 명백히 밝혀지지 않았으나 사용되는 약제 로는 vincristine sulfate, actinomycin, cyclophosphamide, 5-FU, doxorubicin과 bleomycin, doxorubicin과 dimethyl-triazenoimidazolecarboxamide를 병용함으로써 치료효과를 상승시킬 수 있다 고 하였으며, 방사선 치료와 함께 시행할 시 전이가 완화된다는 보고가 있다[13].

방사선 요법은 종양의 크기 감소에 도움이 된다고 하며, 종양의 재발 이나 외과적으로 완전한 제거가 불가능한 경우에 좋은 효과를 얻을 수 있다고 하였다[11].

수술 후 병행요법으로도 호르몬요법, 화학요법, 방사선 요법이 시행되 고 있으나, 재발률이나 생존율에 관한 효과는 논란의 여지가 있다[10].

다양한 연구에서 저등급 $\mathrm{ESS}$ 의 예후를 결정하는 인자로 종양의 크 기, 성장 양상, 유사분열의 수, 병기, 폐경여부, 연령, 조직학적 분화 도, 종양에 의한 수술 변연부의 침범 등을 보고한 적이 있으나, 아직 은 여전히 논란의 여지가 남아있는 상태이다[11]. 종양의 분화 정도 가 저등급 ESS에 대한 임상적 경과의 강력한 예측인자이며, 진행병변 (advanced disease), DNA이수배수체, 그리고 high S phase fraction 이 나쁜 예후와 연관된다는 보고가 있다[14]. Early tumor stage, low myometrial invasion, 그리고 low mitotic count가 긴 생존율과 연관이
있다는 보고도 있었다[15]. 난소에서 발생한 저등급 ESS는 다른 순수 난소 육종에 비해 상당히 예후가 좋다. 그러나 고등급 ESS의 경우에는 일반적인 난소 육종과 예후가 비슷하다고 생각되지만, 확실한 결론을 내리기에는 그 사례가 적다[3].

본 증례에서는 우연히 난소 종괴가 염전되어 복통을 유발함으로써 수술 시행 후 저등급 ESS로 진단받게 되었다. 난소에서 발생하는 자궁 내막기질육종은 많은 경우에서 자궁내막증 또는 자궁에서 유사한 종양 이 발견된다. 그러나 저자들은 자궁내막증 등의 다른 연관질환이나 주 변조직으로의 전이가 없이 난소에만 국한되어 명확히 난소 기원이라고 할 수 있는 대단히 드문 원발성 난소의 저등급 자궁내막기질육종 1 예 를 경험하였기에 문헌고찰과 함께 이를 보고하는 바이다.

\section{References}

1. Baiocchi G, Kavanagh JJ, Wharton JT. Endometrioid stromal sarcomas arising from ovarian and extraovarian endometriosis: report of two cases and review of the literature. Gynecol Oncol 1990:36:147-51.

2. Harlow BL, Weiss NS, Lofton S. The epidemiology of sarcomas of the uterus. J Natl Cancer Inst 1986;76:399-402.

3. Young RH, Prat J, Scully RE. Endometrioid stromal sarcomas of the ovary. A clinicopathologic analysis of 23 cases. Cancer 1984;53:1143-55.

4. Chang KL, Crabtree GS, Lim-Tan SK, Kempson RL, Hendrickson MR. Primary uterine endometrial stromal neoplasms. A clinicopathologic study of 117 cases. Am J Surg Pathol 1990;14:41538.

5. Fukunaga $M$, Ishihara $A$, Ushigome S. Extrauterine low-grade endometrial stromal sarcoma: report of three cases. Pathol Int 1998:48:297-302.

6. Oliva E, Clement PB, Young RH. Endometrial stromal tumors: an update on a group of tumors with a protean phenotype. Adv Anat Pathol 2000;7:257-81.

7. Berek JS, Novak E. Berek \& Novak's gynecology. 15th ed. Philadelphia (PA): Lippincott Williams \& Wilkins; 2012.

8. Piver MS, Rutledge FN, Copeland L, Webster K, Blumenson L, Suh 0 . Uterine endolymphatic stromal myosis: a collaborative study. Obstet Gynecol 1984;64:173-8.

9. Franquemont DW, Frierson HF Jr, Mills SE. An immunohistochemical study of normal endometrial stroma and endometrial stromal neoplasms. Evidence for smooth muscle differentiation. Am J Surg Pathol 1991;15:861-70.

10. Nordal RR, Kristensen GB, Kaern J, Stenwig AE, Pettersen EO, Tropé CG. The prognostic significance of surgery, tumor size, 


\section{KOREAN JOURNAL OF OBSTETRICS \& GYNECOLOGY}

Woo Hee Yi, et al. Primary ovarian low-grade ESS

malignancy grade, menopausal status, and DNA ploidy in endometrial stromal sarcoma. Gynecol Oncol 1996;62:254-9.

11. Gloor E, Schnyder P, Cikes M, Hofstetter J, Cordey R, Burnier $F$, et al. Endolymphatic stromal myosis. Surgical and hormonal treatment of extensive abdominal recurrence 20 years after hysterectomy. Cancer 1982;50:1888-93.

12. Baker VV, Walton LA, Fowler WC Jr, Currie JL. Steroid receptors in endolymphatic stromal myosis. Obstet Gynecol 1984;63:72S-4S.

13. Lehrner LM, Miles PA, Enck RE. Complete remission of widely metastatic endometrial stromal sarcoma following combination chemotherapy. Cancer 1979;43:1189-94.

14. Blom R, Malmström $H$, Guerrieri C. Endometrial stromal sarcoma of the uterus: a clinicopathologic, DNA flow cytometric, p53, and mdm-2 analysis of 17 cases. Int J Gynecol Cancer 1999;9:98-104.

15. Bodner K, Bodner-Adler B, Obermair A, Windbichler G, Petru $E$, Mayerhofer $S$, et al. Prognostic parameters in endometrial stromal sarcoma: a clinicopathologic study in 31 patients. Gynecol Oncol 2001;81:160-5.

\section{난소에서 일차적으로 기원한 저등급 자궁내막기질육종 1예}

\section{부산성모병원 ${ }^{1}$ 산부인과학교실, ${ }^{2}$ 병리학교실}

이우희 ${ }^{1}$, 신규식 ${ }^{1}$, 제구화 ${ }^{1}$, 이화선 ${ }^{2}$, 백경돈 $^{1}$

자궁내막기질육종은 자궁육종의 비교적 드문 형태로 자궁에서 발생하는 악성 종양의 약 $0.2 \%$ 를 차지하고 있다. 저등급 자궁내막기질육 종의 약 $40 \%$ 에서는 자궁외 부위에 전이된 상태로 진단된다. 난소에서 발생하는 자궁내막기질육종은 매우 희귀한 질환이며, 많은 경우에 서 자궁내막증 또는 자궁에서 유사한 종양이 발견된다. 저자들은 난소에만 국한되어 명확히 난소 기원이라 할 수 있는 저등급 자궁내막기 질육종 1예를 경험하였기에 문헌고찰과 함께 보고하는 바이다.

중심단어: 저등급 자궁내막기질육종, 난소 신생물 